\title{
An Experimental Analysis of the Impact of Tree Shade on Electricity Consumption
}

\author{
David N. Laband and John P. Sophocleus
}

\begin{abstract}
Trees cast shade on homes and buildings, lowering the inside temperatures and thus reducing the demand for power to cool these buildings during hot times of the year. The potential monetary savings may be sizable, especially for those who live in hot climates, because electricity usage for cooling residential and commercial structures in summer months is costly. A controlled experiment was conducted to quantify the impact of tree shade on electricity consumption devoted exclusively to cooling a structure. We examine electricity consumption used to run air conditioning units set at identical temperatures in two otherwise identical buildings, one set in full sun, the other in full shade during the summer months of 2008 in Beauregard, Alabama. The building in full sun required 2.6 times more electricity for cooling than the building in full shade. Our findings contribute to a growing body of research which demonstrates that owners of residential and commercial properties located in hot regions can reap sizable monetary savings from shade trees that serve as natural complements to their artificial air-conditioning.

Key Words. Energy Savings; Natural Cooling; Tree Shade.
\end{abstract}

Trees affect the well-being of humans in a variety of ways. In large measure, the impacts are positively-valued. For example, trees are aesthetically pleasing, are a source of energy for heating and cooking, provide habitat for other plant and animal species valued by humans, are a source of certain foods and medicines, and provide natural filtration that helps clean water and reduces destructive stormwater runoff. However, in some respects the impacts are negative (e.g., trees fall on power lines, cars, and occasionally people, they may enhance risk of fire, and heavy tree shade may increase the amount of electricity needed to adequately light a structure).

Most of these economic values have not been measured/estimated. However, a number of researchers have examined the impact of urban trees on residential energy consumption. Trees cast shade on homes and buildings, lowering the inside temperatures and thus reducing the demand for power to cool these buildings during hot times of the year. The potential monetary savings may be sizable, especially for those who live in hot climates, because electricity usage for cooling residential and commercial structures in summer months is costly. In the Sun Belt region of the U.S., the energy used for air conditioning makes up a large fraction of the peak electrical utility loads during the warmest period of summer (Rudie and Dewers 1984). As the cost of electricity continues to climb, the economic incentive for homeowners to find ways to conserve on energy use grows correspondingly.

This paper presents the results of a controlled experiment conducted to quantify the impact of tree shade on electricity consumption devoted exclusively to cooling a structure.

\section{LITERATURE REVIEW}

Because residential demand for electricity depends on a large number of factors, most analysis of the link between urban tree canopy and residential energy usage has been based on simula- tion exercises. For example, Huang et al. (1987) conducted a simulation study of the potential role of vegetation in reducing summer cooling energy in residential houses located in Lake Charles, Louisiana; Los Angeles, California; Phoenix, Arizona; and Sacramento, California (U.S.). The simulations suggest that an additional $25 \%$ increase in tree cover would reduce annual cooling energy use by $40 \%, 25 \%$, and $25 \%$ for an average house in Sacramento, Phoenix, and Lake Charles, respectively. However, the calculated savings for Los Angeles were minimal. Simpson and McPherson (1996) used simulation analysis to suggest that two trees shading the west-facing exposure of a house and one tree shading the east-facing exposure would reduce annual energy use for cooling by $10 \%$ to $50 \%$ and peak electrical use up to $23 \%$. Similarly, McPherson et al. (1997) estimated that three $7.6 \mathrm{~m}(25 \mathrm{ft})$ tall trees around a well-insulated new house located in Chicago, Illinois would reduce annual heating and cooling costs by $8 \%$ as compared to an otherwise identical house without trees. Akbari et al. (1997) analyzed the impact of shade trees on peak power and cooling energy use in two houses in Sacramento, and found a $30 \%$ reduction in energy use and 0.6 to $0.8 \mathrm{kWh}$ peak demand savings due to shade trees.

In a compelling analysis, Rudie and Dewers (1984) examined the impact of shade cast in different coverage categories on energy consumption by 113 residences in College Station, Texas. Over a three-year period (1977-1979), they used measured tree height to estimate the amount of shade cast on roofs on the 21st day of June, July, August, and September. They developed a shade score for each home ranging from 1 to 4 based on the shaded roof perimeter and wall space, and classified each home into one of 4 shade categories to analyze energy savings as a result of tree shade. Their findings for different shade categories indicated that the amount of shade, roof color, and wall color were significant determinants of residential energy consumption. 
If the amount of shade cast is a significant predictor of shaderelated energy savings, a logical implication is that type of tree (species, shape, height) will be an important consideration with respect to determining the extent and density of shade cast and therefore the extent of possible energy savings. The relationship between species composition and shade-related energy savings has been investigated by DeWalle et al. (1983), who measured energy used for heating/cooling in mobile homes surrounded by deciduous trees versus pine trees in the state of Pennsylvania. They found that deciduous trees contributed significant energy savings for summertime cooling while the presence of pine trees increased wintertime heating costs more than the presence of deciduous trees. However, their analysis focused exclusively on mobile homes, where the relatively poor insulation should imply relatively large energy savings from the presence of shade trees.

McPherson and Dougherty (1989) investigated both energy savings from shade-related cooling of houses and water use for several species of trees in Tucson, Arizona. They report that both tree shape and crown density have significant impacts on shade-related energy savings.

Jensen et al. (2003) used remote sensing data to measure Leaf Area Index (LAI) at 118 randomly-selected locations in Terre Haute, Indiana. They regressed residential energy consumption against LAI values and failed to find a statistically significant relationship. These results are in contrast to the strong and significant impact of shade trees on residential energy consumption identified by other studies.

\section{METHODS}

The general methodology for this study was to compare electricity consumption used to maintain a constant temperature in two otherwise identical buildings, situated in different shade conditions. This would permit one to estimate with a high degree of accuracy the cooling impact of shade trees, untainted by confounding effects. Specifically, testing whether the electricity required to cool a building situated in full sun was significantly greater than the electricity required to cool an otherwise similar building located in heavy shade.

The study authors acquired two $10 \mathrm{ft} \times 16 \mathrm{ft}(3 \mathrm{~m} \mathrm{x} 4.9 \mathrm{~m})$ storage sheds with identical construction specifications. Each building was manufactured with a dark gray, shingled roof that included a ridge vent and six windows. Once on-site, both buildings were fully insulated with R-13 batting. In addition, linoleum was installed over the plywood floors and the corners were secured with quarter-round molding. The intent was to create, in effect, miniature residences. Finally, each building was wired with electrical current with installed outlets.

These buildings were located on a property in Beauregard, Alabama, U.S. at $32.534283^{\circ} \mathrm{N}$ Latitude and $85.356333^{\circ} \mathrm{W}$ Longitude. One building was located in full sunshine (Apollo); the other was located approximately $130(40 \mathrm{~m})$ feet away in dense shade (Hades). Specific information with respect to the light conditions on each building is presented in Appendix 1. In such close proximity, it seems unlikely that the differences in cooling effort reported result from significant differences in local climatic conditions (e.g., cloud cover, thermals). The two buildings were situated in the same spatial configuration relative to the arc of the sun.

Identical window air conditioning units were installed in each building. The air conditioners were Sears-Model number:
580.75051, Cooling capacity: 5,300 BTU, Watts: 490, EER: 10.8 BTU/hr, Volts: $115 ; 60 \mathrm{~Hz}$, Amps: 4.6 (single phase). The thermostat on each was set to $72^{\circ} \mathrm{F}\left(22^{\circ} \mathrm{C}\right)$. These $\mathrm{AC}$ units were plugged directly into data loggers that record electricity use; readings were taken daily. This was the only draw on the electrical current supplied to each building. In addition, daily information was recorded on the minimum and maximum interior temperature using battery-operated recorders. These recorders were located slightly above and to the right of each $\mathrm{AC}$ unit, at a height of $5 \mathrm{ft}(1.5 \mathrm{~m})$ from ground level. Finally, the study used Hobo weather stations located $6 \mathrm{ft}(1.8 \mathrm{~m})$ due south of each building to collect information at 15-minute intervals on outside temperature, humidity, and light conditions.

Independently of compressor-active cooling, the AC units used identical amounts of electricity per day to run their respective fan motors and display the thermostat setting. Consistency in this regard was checked by observing the current draws in each building on a day when the temperature never exceeded $70^{\circ} \mathrm{F}$ $\left(21^{\circ} \mathrm{C}\right)$ (thus, there was no compressor-driven cooling). Because the fan motors on the AC units ran continuously, the study authors identified the daily current draw for noncooling purposes $(1.04 \mathrm{~kW})$ and subtracted this number from the recorded daily usage to derive the daily power used to cool each building.

In terms of light conditions, the Hobo weather stations recorded Photosynthetically Active Radiation (PAR) values, which is the spectral range of solar light from 400 to $700 \mathrm{~nm}$ that is needed by plants for photosynthesis (actinic UVA to infrared). Mean PAR at each building was calculated from the nonnighttime readings.

Data collection was from April 1, 2008-September 17, 2008 (Appendix 1). Unfortunately, the temperature sensor on the Hobo station positioned next to Hades started malfunctioning in midJuly; as a result, the study does not have a complete series of temperature readings for said building. Because the study authors had incomplete data for Hades on external temperatures, there was an estimation of the statistical relationship between the external temperatures recorded at Apollo and those recorded at Hades. The study authors then used a regression model to assign estimated values for mean outside temperature and outside high temperature at Hades for the period July 18, 2008-September 17, 2008. For mean outside temperature, the estimated predictive model was: $\mathrm{y}=2.089951+0.965314$ Apollo temp. The regression $\mathrm{R}^{2}$ value is 0.99869 ; the model F-statistic is $77,004.32$. For mean high temperature, the estimated predictive model was: $\mathrm{y}=4.0775544+0.912341$ Apollo temp. The regression $\mathrm{R}^{2}$ value is 0.98235 ; the model F-statistic is 5620.895 . Judging both by the $\mathrm{R}^{2}$ values and model F-statistics, these simple models have very high predictive ability. As a result, the study authors are confident that the imputed values for Hades are sufficiently accurate as to not compromise the integrity of their analysis.

\section{RESULTS}

It is quite evident that light conditions varied substantially between Apollo and Hades. The t-tests of differences in mean PAR for each month were reported for the study period; all show that mean PAR was significantly higher in Apollo than Hades. Additional reporting noted t-tests of differences in electricity used to cool each building for each month in our study period (Table 1). Again, consistent evidence was found, by month, that electricity consumption per day was significantly 
higher in Apollo than in Hades. The mean power use for cooling Hades (Apollo) over the entire sample period was 1.25 (3.26) $\mathrm{kWh}$ /day. In percentage terms, Apollo required 2.6 times the electricity for cooling than did Hades. At the local rate of $\$ 0.13 / \mathrm{kWh}$, it cost approximately $\$ 7.84$ more per month to cool Apollo as compared to Hades, at the $72^{\circ} \mathrm{F}$ thermostat setting.

Reinforcing this result is an Ordinary Least Squares (OLS) estimation of a simple linear regression model with $\mathrm{kWh} /$ day as the dependent variable, the intercept forced through 0 , and a dummy variable assigned a value of 1 for readings from Apollo and 0 for readings from Hades, for the entire period of our study (April 1, 2008-September 17, 2009). The estimated coefficient on the Apollo dummy variable is 3.283 , with a standard error of $0.123(t=26.69)$. The model F-statistic is 710.535 .

These findings provide compelling evidence that the amount of electricity used each day to cool the building in full sun (Apollo) was significantly greater than the amount of electricity used each day to cool the building in deep shade (Hades). However, beyond this, they shed no empirical light on the linkage between the amount of light and/or external temperature and the amount of electricity used for cooling. To explore this relationship, OLS regression was used to estimate the models reported in Table 2.
Because there was literally no draw on the circuit feeding into the current logger other than the AC unit, the intercept in each model was forced to be equal to zero. It was expected that energy used for cooling each building would increase with the amount of sunlight (mean and maximum) on the building and with daytime temperature (mean and maximum). Although the structural models reported in Table 2 are linear, the study authors estimated nonlinear models as well. However, they did not find consistent evidence of nonlinear relationships and the estimated nonlinearities were so slight that turning points were well outside the meaningful range of temperatures and light values.

At a thermostat setting of $72^{\circ} \mathrm{F}$ and starting from the sample mean electricity usage $(3.26 \mathrm{kWh} /$ day $)$, it was estimated that for every additional $10^{\circ}$ increase in the mean outside temperature there was an additional $0.191 \mathrm{kWh} /$ day $(5.9 \%)$ for cooling, and for every $10^{\circ}$ increase in the maximum outside temperature there was an additional $0.166 \mathrm{kWh} /$ day $(5.1 \%)$ for cooling. Likewise, in terms of light conditions (PAR) on the two buildings, the study estimated that starting from the sample mean of 614.55 (full sun) each $10 \%$ reduction in mean PAR would reduce electricity used for cooling by approximately $0.172 \mathrm{kWh} /$ day $(5.3 \%)$. Therefore, tree shade that lowered mean PAR on a house by, say, 25\% would reduce electricity used for cooling by approximately $13 \%$.

Table 1. Comparison of Light Conditions (PAR) and Electricity Used for Cooling (kWh) Between Apollo and Hades.

\begin{tabular}{|c|c|c|c|c|c|c|}
\hline \multirow[b]{2}{*}{ Time Period } & \multicolumn{2}{|c|}{ Mean PAR } & \multirow[b]{2}{*}{ t-statistic } & \multicolumn{2}{|c|}{ kWh/day } & \multirow[b]{2}{*}{ t-statistic } \\
\hline & Apollo & Hades & & Apollo & Hades & \\
\hline April & 609.24 & 153.07 & $12.12^{z}$ & 1.33 & 0.28 & $7.86^{2}$ \\
\hline May & 655.18 & 57.05 & $18.75^{z}$ & 2.56 & 0.65 & $7.87^{z}$ \\
\hline June & 684.71 & 50.11 & $22.92^{z}$ & 4.71 & 1.93 & $10.69^{z}$ \\
\hline July & 650.96 & 41.55 & $29.06^{2}$ & 4.40 & 1.80 & $15.18^{z}$ \\
\hline August & 543.44 & 50.12 & $14.89^{z}$ & 3.61 & 1.47 & $8.15^{z}$ \\
\hline September $1-17$ & 506.87 & 47.89 & $14.07^{z}$ & 3.33 & 1.45 & $6.59^{\mathrm{z}}$ \\
\hline
\end{tabular}

${ }^{\mathrm{z}} \mathrm{t}$-value statistically significant at 0.01 level.

Table 2. OLS regression estimation of factors affecting electricity used for cooling. Dependent variable: kWh/day.

\begin{tabular}{|c|c|c|c|}
\hline Explanatory Variable & (expected sign) & $\begin{array}{l}\text { Coefficient } \\
\text { Estimate } \\
\text { (Std. Error) }\end{array}$ & $\begin{array}{l}\text { Coefficient } \\
\text { Estimate } \\
\text { (Std. Error) }\end{array}$ \\
\hline Mean daily PAR ${ }^{z}$ & $(+)$ & $\begin{array}{c}0.0028^{y} \\
(0.0002)\end{array}$ & \\
\hline Mean daily high temperature ${ }^{x}$ & $(+)$ & $\begin{array}{r}0.0191^{y} \\
(0.0015)\end{array}$ & \\
\hline Maximum daily high PAR ${ }^{\mathrm{w}}$ & $(+)$ & & $\begin{array}{r}0.0008^{y} \\
(0.0001)\end{array}$ \\
\hline Maximum daily high temperature ${ }^{v}$ & $(+)$ & & $\begin{array}{c}0.0166^{y} \\
(0.0020)\end{array}$ \\
\hline $\begin{array}{l}\mathrm{R}^{2} \\
\mathrm{~F}(\text { model }) \\
\mathrm{N}\end{array}$ & $\begin{array}{l}\quad 0.8014 \\
631.40 \\
316.00\end{array}$ & $\begin{array}{l}\quad 0.7566 \\
486.35 \\
316.00\end{array}$ & \\
\hline
\end{tabular}

${ }^{\mathrm{z}}$ Daily PAR readings averaged across readings taken at 15 -minute intervals, non-nighttime (PAR $>0$ ).

y coefficient statistically significant at 0.01 level.

${ }^{x}$ Daily temperature averaged across readings taken at 15 -minute intervals, nonnighttime (PAR $\left.>0\right)$.

${ }^{w}$ The highest PAR value each day.

v The highest temperature each day. 


\section{DISCUSSION}

The cooling effect of trees is most important during the period of maximum temperature and solar radiation (Parker 1983). Therefore, shade trees can be plausibly considered as a possible demand side management resource to provide cost-effective energy savings to homeowners and business owners (Simpson and McPherson 1996). These findings suggest that such savings may be sizable. As noted previously, Apollo required 2.6 times the electricity for cooling than did Hades. The estimated additional cost to cool Apollo (\$7.84 per month) may not seem like much, however the annual cost is approximately $\$ 95$. Further, this is for a very small area $\left(160 \mathrm{ft}^{2} / 14.9 \mathrm{~m}^{2}\right)$. The cost savings associated with the energy required to cool a space 10 times this size, which closely approximates the size of many actual dwellings, would surely be well above $\$ 500$ per year, even acknowledging the relative cost efficiency of central air conditioning over window units (Pandit and Laband 2008).

Moreover, as has been demonstrated previously (DeWalle et al. 1983; McPherson and Dougherty 1989; Laverne and Lewis 1996; Simpson and McPherson 1996; Pandit and Laband 2008), shade that hits a building in the late afternoon, when temperature build-up peaks, has a greater impact on energy used for cooling than shade at other times of the day. Thus, $25 \%$ shade on a dwelling during the hottest time of the day likely would have a greater impact on energy consumption than the $13 \%$ reduction suggested earlier, since the figure was derived from mean shade coverage irrespective of time of day.

Other aspects of the data reported in Appendix 1 are noteworthy. For example, the maximum inside temperatures recorded in Apollo consistently exceed those recorded in Hades by $5-6^{\circ} \mathrm{F}$. Moreover, the standard deviations around those monthly means are considerably higher in Apollo than Hades. In both cases the recorded high temperatures exceed the $72^{\circ}$ thermostat setting. In some measure, this likely reflects air circulation patterns. But the quite large differences between the maximum temperatures recorded in Apollo (the numbers reported in Table 1 are average high temperatures each month) and the thermostat setting strongly suggest that the AC units were not able to fully handle the cooling job required. This implies that if the study had AC units in place that were able to properly cool to the thermostat setting, the measured difference in electricity used in Apollo as compared to Hades would have been even greater than reported. That is, the findings almost certainly understate the true impact of tree shade.

Obviously, this experimental design contrasts electricity used for cooling a building in full sun against a building in essentially full shade - the two ends of a wide spectrum. Few people live in, or want to live in, full shade. Therefore, future experiments focusing on buildings with partial shade will presumably command a good deal of interest. In addition, it seems possible, if not likely, that these findings will be sensitive to the thermostat setting, the color of the roof, how well insulated the buildings are, and a host of other conditions that were held constant. The experimental methodology used is flexible enough to permit researchers to identify quite precise impacts of specific factors under control that influences electricity consumption used for cooling, by systematically varying a single variable at a time; such as the thermostat level, roof colors, the impact of insulation with different R-values, the impact of low-E and/or tinted glass, or the impact of blinds/shades. Tightly-calibrated empirical estimates of these impacts are within reach and it is hoped that future researchers will continue to pursue this line of research.

Taken together, this growing body of research demonstrates that owners of residential and commercial properties located in hot regions can reap sizable monetary savings from shade trees that serve as natural complements to their artificial air-conditioning. The industry now needs to find ways to get this scientific information to the builders and owners of residential and commercial properties who make decisions about those properties. If their perception of mature trees located in close proximity to their property is that they increase risk with little offsetting benefits, they are unlikely to take advantage of the energy savings available from the shade provided. Knowledge of the possible size of the benefits should at a minimum permit more informed decisionmaking with respect to whether or not mature trees are stripped off a residential construction site and/or whether a homeowner cuts down mature trees that are close enough to fall on his residence.

Acknowledgments. This research was supported by a competitive McIntire-Stennis grant awarded to Laband through the SFWS at Auburn University. We appreciate the assistance and shared expertise of Ed Loewenstein and helpful comments received from the Associate Editor and two anonymous reviewers. We are solely responsible for any shortcomings in the analysis or presentation

\section{LITERATURE CITED}

Akbari, H., D.M Kurn, S.E. Bretz, and J.W. Hanford. 1997. Peak power and cooling energy savings of shade trees. Energy and Buildings 25:139-148.

DeWalle, D.R., G.M. Heisler, and R.E. Jacobs. 1983. Forest home sites influence heating and cooling energy. Journal of Forestry 81(2):84-88.

Huang, Y.J., H. Akbari, H. Taha, and A.H. Rosenfeld. 1987. The potential of vegetation in reducing summer cooling loads in residential buildings. Journal of Applied Meteorology 26(9):1103-1116.

Jensen, R. J.R. Boulton, and B.T. Harper. 2003. The relationship between urban leaf area and household energy usage in Terre Haute, Indiana, U.S. Journal of Arboriculture 29:226-230.

Laverne, R.J., and G.M.D. Lewis. 1996. The effect of vegetation on residential energy use in Ann Arbor, Michigan. Journal of Arboriculture 22:234-243.

McPherson, E.G., and E. Dougherty. 1989. Selecting trees for shade in the Southwest. Journal of Arboriculture 15(2):35-43.

McPherson, E.G., D. Nowak, G. Heisler, S. Grimmond, C. Souch, R. Grant, and R. Rowntree. 1997. Quantifying urban forest structure, function, and value: the Chicago Urban Forest Climate Project. Urban Ecosystems 1:49-61.

Pandit, R., and D.N. Laband. 2008. A hedonic analysis of the impact of tree shade on summertime residential energy consumption, unpublished manuscript.

Rudie, R.J., and R.S. Dewers. 1984. Effects of tree shade on home cooling requirements. Journal of Arboriculture 10:320-322.

Simpson, J.R., and E.G. McPherson. 1996. Potential of tree shade for reducing residential energy use in California. Journal of Arboriculture 22:10-18. 
David N. Laband (corresponding author)

Professor

Economics and Policy, School of Forestry \& Wildlife Sciences

Auburn University, 602 Duncan Drive

Auburn, AL 36849-5418, U.S.

334-844-1074

labandn@auburn.edu

John P. Sophocleus

Adjunct Instructor

Department of Economics

Auburn University Montgomery

Montgomery, AL 36124-4023, U.S.

Résumé. Les arbres projettent de l'ombre sur les maisons et les édifices, diminuant de ce fait les températures à l'intérieur et donc la demande énergétique pour rafraichir ces bâtiments durant les périodes chaudes de l'année. Les économies monétaires potentielles peuvent être mesurées, spécifiquement pour ceux qui vivent sous des climats chauds, parce que la consommation d'électricité pour la climatisation des résidences et des bâtiments commerciaux en été est coûteuse. Une expérimentation contrôlée a été menée pour quantifier l'impact des arbres ornementaux sur la consommation d'électricité dévolue exclusivement pour la climatisation. Nous avons étudié la consommation employée pour faire fonctionner des unités de climatisation sous des températures similaires dans deux édifices identiques, un exposé au plein soleil et l'autre entièrement ombragé durant les mois d'été de 2008 à Beauregard en Alabama. L'édifice en plein soleil exigeait 2,6 fois plus d'électricité pour la climatisation que l'édifice en entièrement ombragé. Nos recherches contribuent à un ensemble de recherches grandissantes qui démontrent que les propriétaires résidentiels et commerciaux localisés dans des régions chaudes peuvent récolter des économies d'argent appréciables de l'ombrage des arbres qui servent de complément naturel à la climatisation artificielle.
Zusammenfassung. Bäume spenden Schatten für Gebäude, senken die Temperaturen im Gebäude und reduzieren damit den Energieverbrauch von Klimaanlagen während der heißen Jahreszeit. Die potentiellen Einsparungen können variieren, besonders für solche, die in heißen Klimaten wohnen, da der Stromverbrauch für Klimaanlagen in den Sommermonaten besonders kostspielig ist. Ein kontrolliertes Experiment wurde durchgeführt, um den Einfluss von Schattwirkungen von Bäumen auf den ausschließlichen Stromverbrauch für Kühlung zu quantifizieren. Wir untersuchten den Stromverbrauch von Klimaanlagen bei identischen Temperaturen in zwei ansonsten identischen Gebäuden, eine in der vollen Sonne und eine voll im Schatten in Beauregard, Alabama. Das Gebäude mit voller Sonneneinstrahlung verbrauchte 2,6 mal so viel Strom als das beschattete Gebäude. Unsere Ergebnisse tragen zu einem wachsenden Verständnis und Wissen bei, Hauseigentümern in warmen Regionen zu zeigen, erhebliche Kosten an Strom einzusparen, wenn ihre Gebäude von Bäumen beschattet werden und den Wirkungsgrad der Klimaanlage verbessern.

Resumen. Los árboles proporcionan sombra en residencias y edificios, disminuyendo la temperatura interior y por tanto reduciendo la demanda de energía para enfriar esas edificaciones durante las épocas calurosas del año. El potencial ahorro monetario puede ser cuantificable, especialmente para quienes viven en climas calientes, debido a que la electricidad usada para enfriar las estructuras residenciales y comerciales en el verano es costosa. Se condujo un experimento controlado para cuantificar el impacto de la sombra de los árboles en el consumo de electricidad debida exclusivamente al enfriamiento de una estructura. Se examinó el consumo de electricidad usada para el aire acondicionado a idénticas temperaturas en dos edificios idénticos, uno a pleno sol, y el otro con sombra en los meses del verano de 2008 en Beauregard, Alabama. El edificio en pleno sol requirió 2.6 veces más electricidad para el enfriamiento que el edificio son sombra. Estos hallazgos contribuyen al crecimiento de un cuerpo de investigación que demuestra que los propietarios de edificios comerciales y residenciales localizados en regiones cálidas pueden lograr ahorros considerables de dinero con los árboles de sombra que sirven como un complemento natural a sus acondicionadores de aire artificiales. 
APPENDIX 1. SAMPLE STATISTICS FOR APOLLO AND HADES

\begin{tabular}{|c|c|c|c|c|c|c|c|}
\hline & $\mathrm{kWh} /$ day & $\begin{array}{l}\text { mean } \\
\text { PAR }\end{array}$ & $\begin{array}{l}\max \text { inside } \\
\text { temp }\end{array}$ & $\begin{array}{l}\text { Apollo (sun) } \\
\text { min inside } \\
\text { temp }\end{array}$ & $\begin{array}{l}\max \text { outside } \\
\text { temp }\end{array}$ & $\begin{array}{l}\text { min outside } \\
\text { temp }\end{array}$ & $\mathrm{N}$ \\
\hline April & $\begin{array}{c}1.33 \\
(0.87)\end{array}$ & $\begin{array}{c}609.24 \\
(188.97)\end{array}$ & $\begin{array}{l}78.55 \\
(5.28)\end{array}$ & $\begin{array}{l}52.24 \\
(8.26)\end{array}$ & $\begin{array}{l}77.22 \\
(7.84)\end{array}$ & $\begin{array}{l}50.72 \\
(8.15)\end{array}$ & 30 \\
\hline May & $\begin{array}{c}2.56 \\
(1.17)\end{array}$ & $\begin{array}{c}655.18 \\
(163.89)\end{array}$ & $\begin{array}{l}82.00 \\
(3.89)\end{array}$ & $\begin{array}{l}58.92 \\
(5.99)\end{array}$ & $\begin{array}{l}83.68 \\
(4.19)\end{array}$ & $\begin{array}{l}57.77 \\
(5.69)\end{array}$ & 28 \\
\hline June & $\begin{array}{c}4.71 \\
(0.90)\end{array}$ & $\begin{array}{c}684.71 \\
(142.94)\end{array}$ & $\begin{array}{l}86.14 \\
(4.29)\end{array}$ & $\begin{array}{l}67.58 \\
(2.94)\end{array}$ & $\begin{array}{l}92.46 \\
(3.27)\end{array}$ & $\begin{array}{l}65.95 \\
(2.94)\end{array}$ & 27 \\
\hline July & $\begin{array}{c}4.40 \\
(0.79)\end{array}$ & $\begin{array}{c}650.96 \\
(110.50)\end{array}$ & $\begin{array}{l}83.27 \\
(2.18)\end{array}$ & $\begin{array}{l}69.01 \\
(3.07)\end{array}$ & $\begin{array}{l}93.39 \\
(2.48)\end{array}$ & $\begin{array}{l}67.72 \\
(3.47)\end{array}$ & 28 \\
\hline August & $\begin{array}{c}3.61 \\
(1.29)\end{array}$ & $\begin{array}{c}543.44 \\
(176.51)\end{array}$ & $\begin{array}{l}81.51 \\
(3.63)\end{array}$ & $\begin{array}{l}69.41 \\
(2.71)\end{array}$ & $\begin{array}{l}89.24 \\
(5.73)\end{array}$ & $\begin{array}{l}68.72 \\
(3.33)\end{array}$ & 29 \\
\hline September 1-17 & $\begin{array}{c}3.33 \\
(1.04)\end{array}$ & $\begin{array}{c}506.87 \\
(133.29)\end{array}$ & $\begin{array}{l}80.16 \\
(2.34)\end{array}$ & $\begin{array}{l}65.59 \\
(4.92)\end{array}$ & $\begin{array}{l}87.98 \\
(4.92)\end{array}$ & $\begin{array}{l}68.42 \\
(3.97)\end{array}$ & 17 \\
\hline April - September 17 & $\begin{array}{c}3.26 \\
(1.58)\end{array}$ & $\begin{array}{c}614.55 \\
(316.64)\end{array}$ & $\begin{array}{l}82.06 \\
(4.52)\end{array}$ & $\begin{array}{l}63.93 \\
(8.38)\end{array}$ & $\begin{array}{l}87.14 \\
(7.70)\end{array}$ & $\begin{array}{l}62.72 \\
(8.56)\end{array}$ & 159 \\
\hline
\end{tabular}

\begin{tabular}{|c|c|c|c|c|c|c|c|}
\hline & kWh/day & $\begin{array}{l}\text { mean } \\
\text { PAR }\end{array}$ & $\begin{array}{l}\text { max inside } \\
\text { temp }\end{array}$ & $\begin{array}{l}\text { Hades (shade) } \\
\text { min inside } \\
\text { temp }\end{array}$ & $\begin{array}{l}\text { max outside } \\
\text { temp }\end{array}$ & $\begin{array}{l}\text { min outside } \\
\text { temp }\end{array}$ & $\mathrm{N}$ \\
\hline April & $\begin{array}{c}0.28 \\
(0.42)\end{array}$ & $\begin{array}{l}153.07 \\
(74.23)\end{array}$ & $\begin{array}{l}73.64 \\
(4.34)\end{array}$ & $\begin{array}{l}54.15 \\
(7.55)\end{array}$ & $\begin{array}{l}75.10 \\
(7.35)\end{array}$ & $\begin{array}{l}52.08 \\
(7.61)\end{array}$ & 29 \\
\hline May & $\begin{array}{c}0.65 \\
(0.48)\end{array}$ & $\begin{array}{l}57.05 \\
(25.15)\end{array}$ & $\begin{array}{l}76.07 \\
(1.74)\end{array}$ & $\begin{array}{l}60.36 \\
(5.64)\end{array}$ & $\begin{array}{l}80.28 \\
(4.08)\end{array}$ & $\begin{array}{l}58.93 \\
(5.67)\end{array}$ & 27 \\
\hline June & $\begin{array}{l}1.93 \\
(1.01)\end{array}$ & $\begin{array}{c}50.11 \\
(17.15)\end{array}$ & $\begin{array}{l}78.79 \\
(1.20)\end{array}$ & $\begin{array}{l}69.31 \\
(2.54)\end{array}$ & $\begin{array}{l}88.60 \\
(2.65)\end{array}$ & $\begin{array}{l}66.99 \\
(2.66)\end{array}$ & 27 \\
\hline July & $\begin{array}{l}1.80 \\
(0.58)\end{array}$ & $\begin{array}{c}41.55 \\
(10.38)\end{array}$ & $\begin{array}{l}78.51 \\
(0.83)\end{array}$ & $\begin{array}{l}70.04 \\
(2.77)\end{array}$ & $\mathrm{n} / \mathrm{a}$ & $\mathrm{n} / \mathrm{a}$ & 28 \\
\hline August & $\begin{array}{l}1.47 \\
(0.58)\end{array}$ & $\begin{array}{c}50.12 \\
(25.73)\end{array}$ & $\begin{array}{l}76.92 \\
(1.77)\end{array}$ & $\begin{array}{l}70.52 \\
(2.60)\end{array}$ & $\mathrm{n} / \mathrm{a}$ & $\mathrm{n} / \mathrm{a}$ & 29 \\
\hline September 1-17 & $\begin{array}{l}1.45 \\
(0.55)\end{array}$ & $\begin{array}{l}47.89 \\
(17.82)\end{array}$ & $\begin{array}{l}75.68 \\
(1.76)\end{array}$ & $\begin{array}{l}66.84 \\
(4.46)\end{array}$ & $\mathrm{n} / \mathrm{a}$ & $\mathrm{n} / \mathrm{a}$ & 17 \\
\hline April - September 17 & $\begin{array}{l}1.25 \\
(0.88)\end{array}$ & $\begin{array}{c}47.89 \\
(58.48)\end{array}$ & $\begin{array}{l}76.78 \\
(2.87)\end{array}$ & $\begin{array}{l}64.94 \\
(9.09)\end{array}$ & $\mathrm{n} / \mathrm{a}$ & $\mathrm{n} / \mathrm{a}$ & 157 \\
\hline
\end{tabular}

$\mathrm{n} / \mathrm{a}$ - data not available 